\title{
Contribution of the Activities Diary to the pediatric teaching
}

\author{
Contribuição do Diário de Atividades ao ensino de Pediatria \\ Contribución del Diario de Actividades a la enseñanza de Pediatría
}

\begin{abstract}
Vitor de Almeida Fernandes' ${ }^{1}$ Ana Cláudia B. Scucuglia1 ${ }^{1}$ Ricardo Alessandro T.Gonsaga², Terezinha Soares Biscegli
\end{abstract}
\section{ABSTRACT}

Objective: To describe the fifth-year medical students' self-evaluation based on the reflexive discourse of the Activities Diaries (portfolio) from the Pediatric Internship I and Child Care Rotations.

Methods: Cross sectional, qualitative and descriptive study using the collective subject discourse of the diaries used during the internship of the Medical School, in Catanduva, São Paulo, from January to November, 2011. The registered students' testimonials in the portfolio sections called self-assessment and students' impression were assessed according to their central ideas (discipline organization, breastfeeding outpatient clinic, number of admissions in the pediatric hospital ward and satisfaction with the Child Health training ), related to the teaching of Pediatrics and Child Care. The portfolios with incomplete registers were excluded.

Results: The testimonials of 47 interns $(75 \%$ of the students) were analyzed, and $21.3 \%$ of them expressed satisfaction with the discipline organization and $27.7 \%$ praised the inclusion of the breastfeeding outpatient clinics in the course. For $25.5 \%$ of the academics, the number of admissions in the pediatric wards was insufficient for an ideal learning; however, $70.2 \%$ were satisfied with the Child Health training.

Conclusions: This critical analysis allowed a summary of the reflections, suggestions and critics registered by the interns and can be used as a tool for improvement of the professional cycle.

Key-words: educational measurement; pediatrics; learning; teaching; internship and residency.

Instituição: Curso de Medicina das Faculdades Integradas Padre Albino (Fipa), Catanduva, SP, Brasil

${ }^{1}$ Acadêmico do Curso de Medicina da Fipa, Catanduva, SP, Brasil

${ }^{2}$ Mestre em Ciências da Cirurgia pela Faculdade de Ciências Médicas da Universidade Estadual de Campinas (Unicamp); Professor e Coordenador do Internato do Curso de Medicina da Fipa, Catanduva, SP, Brasil

${ }^{3}$ Doutora em Pediatria pela Faculdade de Medicina de Ribeirão Preto da Universidade de São Paulo (USP); Professora e Coordenadora do Curso de Medicina da Fipa, Catanduva, SP, Brasil

\section{RESUMO}

Objetivo: Descrever a autoavaliação de estudantes do quinto ano de Medicina, a partir do discurso reflexivo dos Diários de Atividades (portfólio) do internato de Pediatria I e Puericultura.

Métodos: Estudo transversal, qualitativo do tipo descritivo, por meio do discurso do sujeito coletivo dos Diários de Atividades utilizados pela coordenadoria de internato do referido curso, localizado em Catanduva, São Paulo, de janeiro a novembro de 2011. Incluíram-se no estudo todos os depoimentos dos alunos, registrados nas seções do portfólio, denominadas autoavaliação e impressão do aluno, as quais contêm as ideias centrais (organização da disciplina, ambulatório de aleitamento materno, número de internações nas enfermarias pediátricas e satisfação com o estágio em Saúde da Criança) relacionadas ao ensino de Pediatria e Puericultura. Excluíram-se os diários com registros incompletos.

Resultados: Analisaram-se os depoimentos de 47 internos do quinto ano (75\% dos discentes), sendo que $21,3 \%$ manifestaram satisfação quanto à organização da disciplina e 27,7\% elogiaram a inclusão do Ambulatório de Aleitamento Materno na graduação. Para 25,5\% dos acadêmicos, o número de internações nas enfermarias de Pediatria foi insuficiente para um aprendizado ideal; entretanto, 70,2\% ficaram satisfeitos com o estágio em Saúde da Criança.

Conclusões: Esta análise crítica permitiu uma organização das reflexões, sugestões e críticas registradas pelos internos e pode ser utilizada como instrumento para aprimoramento do ciclo profissionalizante.

Palavras-chave: avaliação educacional; pediatria; aprendizagem; ensino; internato e residência. 


\section{RESUMEN}

Objetivo: Describir la autoevaluación de estudiantes del quinto año de Medicina, a partir del discurso reflexivo de los Diarios de Actividades (cartera) del internato de Pediatría I y Cuidado del Niño.

Métodos: Estudio transversal, cualitativo de tipo descriptivo, por medio del discurso del sujeto colectivo de los Diarios de Actividades utilizados por la coordinación de internato del referido curso, ubicado en Catanduva, São Paulo (Brasil), de enero a noviembre de 2011. Se incluyeron en el estudio todos los testimonios de los alumnos, registrados en los apartados de la cartera, nombrados autoevaluación e impresión del alumno, los que contienen las ideas centrales (organización de la asignatura, ambulatorio de lactancia materna, número de internaciones en las enfermerías pediátricas y satisfacción con la pasantía en Salud del Niño) relacionadas a la enseñanza de Pediatría y Cuidado del Niño. Se excluyeron los diarios con registros incompletos.

Resultados: Se analizaron los testigos de 47 internos del quinto año (75\% de los alumnos), siendo que el 21,3\% manifestaron satisfacción respecto a la organización de la asignatura y el 27,7\% elogiaron la inclusión del Ambulatorio de Lactancia Materna en la carrera. Para el 25,5\% de los académicos, el número de internaciones en las enfermerías de Pediatría fue insuficiente para un aprendizaje ideal; sin embargo, el 70,2\% resultaron satisfechos con la pasantía en Salud del Niño.

Conclusiones: Este análisis crítico permitió una tabulación de las reflexiones, sugerencias y críticas registradas por los internos en el Diario de Actividades y se puede utilizarlo como instrumento para perfeccionamiento del ciclo profesionalizante.

Palabras clave: evaluación educacional; pediatría; aprendizaje; enseñanza; internato y residencia.

\section{Introduction}

The increasing demand for better life conditions in communities, the change in the epidemiological profile of diseases, the identification of risk factors and new physical and psychosocial diseases, and the development of increasingly more sophisticated and high cost technologies are some of the problems faced by healthcare professionals of the twentyfirst century. In the international scenario, particularly in underdeveloped countries, in the last years there has been a growing interest in children's health ${ }^{(1)}$.
The current context of changes and challenges in training healthcare professionals requires alterations in different spheres - conceptual, interpersonal, social, institutional, and that of values, in order for the training of these professionals to take place in a solid and critical way and also to include the construction of as yet unknown alternatives ${ }^{(2)}$.

In this context, it is observed that the main concern of medical schools is teaching the theoretical background of prevalent childhood diseases. Their Epidemiology, Etiopathogenesis, Pathophysiology, diagnosis and treatment are studied on different occasions of medical training, from first to sixth year ${ }^{(1)}$. Based on this concern with teaching, the Pediatric course at the Medical School of Faculdades Integradas Padre Albino implemented the use of Activities Diary (reflexive portfolio) for intern students, in order to stimulate self-reflection and solidification of the content learned, as well as to know students' opinion on Pediatric training ${ }^{(3-8)}$. The use of the portfolio provides feedback about the information given to students, who, through this practice, are able to describe and discuss their performance in a certain situation or activity. This allows them to be aware of the learning process, because it highlights the dissonances between the intended result and the real one, besides providing data and allowing to review goals, methodology and contents ${ }^{(9)}$.

The Activities Diary was introduced to evaluate students and meet the proposal of internship, which contemplates a critical-reflexive nature, supported in the construction of knowledge from the questioning of reality, with the active participation of the intern in the learning process ${ }^{(10)}$. In this portfolio, the student documents, registers and structures actions, tasks, and learning itself, using a narrative discourse developed in a continuous and reflexive way about the experienced learning activities. Narration changes the way people understand themselves and others. By reading their own narratives, it is possible for future professionals to theorize their own experience ${ }^{(11,12)}$.

Medical education should be directed to the training of people and/or professionals who participate in the process of changing society in a critical and flexible way. So, the "reflexive culture" emerges in the educational scenario, which represents a new attitude towards educational situations and has reached its milestone in the Theory of Inquiry by John Dewey, focused on practical experiences and known as "doing and learning"(13-15).

Based on the foregoing considerations, it was hypothesized that the introduction of a tool for intern's self-evaluation and reflection from the reflexive discourse point of view may contribute to improvement of the teaching of skills in 
Pediatrics in the training of the generalist physician. Thus, this study analyzed the data registered in the Activities Diary of students participating in the internship course in Child Health I (pediatrics I and Child Care) at the Medical School of Faculdades Integradas Padre Albino, during a school year.

\section{Method}

Cross-sectional qualitative study conducted at the internship coordination of the above-mentioned institution, located in Catanduva, northern São Paulo, Brazil. The qualitative methodology was considered appropriate for this study because it allows for the apprehension of the meanings, reasons and aspirations, attitudes, beliefs and values essential for describing and understanding phenomena involving human beings ${ }^{(16)}$.

Data registered in the Activities Diary of students of the first year of internship (fifth year of medical school), from January to November 2011, analyzing interns' selfevaluation and impressions on the training in Pediatrics I and Child Care. All testimonials presenting central ideas were included. Diaries that did not present these ideas or that did not have notes were excluded. The collective subject discourse (CSD) technique was used to know and describe interns' considerations about the training program and to evaluate their reflections ${ }^{(17-19)}$.

Sample power was not calculated due to the methodology employed. According to Fontanella et al ${ }^{(17)}$, "in qualitative studies, the question 'how many?' suggests a relatively secondary importance compared to the question 'who?', although, in practice, they represent inseparable strategies. After all, what is more significant in intentional or intended samples is not the final amount of their elements, but rather the way how the representativeness of these elements is conceived and the quality of the information obtained from them". CSD is a way of presenting results from qualitative investigations, with testimonials as the source of analysis, written in the first person singular, to express the thought of a community as if it was sender of a discourse. This technique allows to extract from the discourse of each individual words or expressions that reveal central ideas and summarize the discourse content ${ }^{(19)}$.

In order to analyze and present the results, the discourse of the very respondent was used, written in the first person singular, composed of key expressions (KE) that presented the same central ideas (CI) and the same anchorage (AC), observing with rigor the order of the following steps:

1) Repeated reading of the answers, which were literally transcribed only after better understanding of the general idea of the discourse.
2) General reading of the answers of each respondent, followed by separate reading of all answers for the question being analyzed.

3) Transcription of the answers for each question in ascending numerical order, highlighting KEs in italics.

4) Individual transcription of each CI with its respective KEs.

5) Extraction of the topic of each of the questions, grouping their respective CIs; finally, construction of CSDs separately from each CI, with its respective KEs.

After CSDs and KEs were summarized, research subjects were grouped into a database using the Epi-Info software, version 3.5.1. The project was approved by the institutional Research Ethics Committee, under the number CAAE 03172712.6.0000.5430.

\section{Results and Discussion}

The study analyzed the self-evaluations of 47 fifth-year interns (75\% of the students), complying rigorously with the described method. Next, CIs that appeared with a significant frequency were described, revealing similar thoughts among the subjects. As for the questions being evaluated, it was chosen to present results and discussion together, because this type of narrative favors the description of qualitative investigations. In order to facilitate understanding, the analysis was subdivided according to the question being analyzed ${ }^{(19-23)}$ :

\section{Organization of the internship course}

An organization is based on a group of people who perform tasks in coordination, acting in a given environment, to achieve a predetermined goal through the effective action of several means and resources, with or without leadership ${ }^{(24)}$.

The analysis of the texts showed that the KE "organization of the course" appeared in $21.3 \%$ of the narratives, which significantly expressed interns' reflection and could be pointed out as one of the strengths of the training in Child Health.

The training program is composed of practical activities at the hospital ward, outpatient clinic, urgency and emergency room, laboratory for child skill development, baby unit, maternity ward, obstetric center, child nutrition, as well as theoretical-practical activities, such as integrative clinical meetings, seminars, and theoretical classes. The internship program in Child Health has a total workload of 400 hours, 200 of which for fifth-year students and 200 for sixth-year students, with 13 professors actively involved in the course. Students are divided into pairs, which alternated between the different training activities, and the analysis of testimonials 
revealed that the structure of the course reflects the organization invested and pleases students, generally speaking ${ }^{(25): ~ " i t ~}$ has an organized syllabus, in which the outlined goals are really met, both in the academic part of reviews of papers and in the classes taught, and in the practical skills acquired for the physical examination and for the understanding of the complementary tests requested and of the therapy chosen for each case" (Intern no. 37).

\section{Breastfeeding}

The World Health Organization (WHO) recommends the practice of exclusive breastfeeding for six months and then the introduction of complementary food until two years of age ${ }^{(26)}$. A total of $22 \%$ of deaths of children under 12 years old could be prevented in the world every year with the practice of exclusive breastfeeding and breastfeeding until one year of age $\mathrm{e}^{(27)}$.

In 2011, in order to meet the needs of the new syllabus of the fifth year of the Medical School, the internship program in Child Health was restructured. Given the importance of breastfeeding, one of the proposals was that interns perform practical activities at the Breastfeeding Outpatient Clinic, with the purpose of training professionals able to guide and stimulate newly-delivered mothers to adhere to this practice. This innovation was praised by $27.7 \%$ of subjects. This outpatient clinic is under the responsibility of an obstetric nurse, who, besides training undergraduate students, also evidences the importance of team and multidisciplinary work, respecting all the elements which compose the logistics of patient care. "Now I know what to say to a mother with difficulty in breastfeeding. I know how to teach what should be done in order for the newborn to suck more during the day than during the night. I know how to instruct on the best position to offer the breast and how to 'grab' appropriately for the baby to suck more productively" (Intern no. 9).

\section{Number of patients}

An important finding registered in the portfolios was students' dissatisfaction with the number of patients treated at outpatient clinics and hospital wards. For 25.5\% of the interns, this number was insufficient for an ideal learning. It is known that many children's complaints are related to climate and seasonal variations, as well as to periods of viral outbreaks, among others, and the number of consultations and admissions may vary according to the time of the year ${ }^{(28)}$. Datasus data from 2008 to 2011 show that the number of pediatric admissions in Catanduva dropped from 1,847 to 1,581 . This reduction of $16 \%$ in this three-year period is probably a reflection of the improvement in prevention and primary care of diseases, which contributed to the scarcity of patients at hospital wards ${ }^{(29,30)}$. "The hospital wards had a reduced number of admitted children, which, for our pair, was a bad thing, but that depends on the period of the year and on the diseases of the season, which, during our training, were not frequent, lucky for the children!" (Intern no. 19). "As for the wards of Hospital Escola Emílio Carlos, despite the reduced number of patients, training was compensated by the detailed discussion of the cases" (Intern no. 28).

\section{Satisfaction with the training program}

The teaching plan outlined by internship course coordinators aims to develop skills and competences, as well as to deepen in practice the knowledge acquired in the training cycle of medical school, aiming for an ethical and high quality training for the generalist physician, which is necessary to train physicians to recognize and follow the child being treated, either at the outpatient level, in urgency and emergency services, or during hospital admission ${ }^{(25)}$. When looking for keywords related to satisfaction with the training program, it was observed that $70.2 \%$ of students commended the faculty and the structure of the program, which reflected in a successful achievement of the learning goals. "The training program in Pediatrics is very well formatted, counting on the really active participation of professors, a fact that grounds and materializes the theoretical knowledge on diseases, with all the complementary tests and conducts" (Intern no. 35). "In this month of activity, I was able to come across with the most frequent and common conditions in pediatric practice, having the opportunity to learn how to identify, and thus treat, them, and now I can state that I feel confident and capable of, in the future, dealing with cases similar to those I followed during my practice as an intern" (Intern no. 45).

The introduction of the Activities Diary in interns' routine helped in the control of the quality of learning and in the organization of the internship, leading to improvements in the teaching-learning process. It is used as a tool for selfreflection, a vehicle for students to make criticisms and suggestions, and a feedback for professionals who deal directly with the students (professors and preceptors), allowing to improve the methods of knowledge transfer and to teach a more human doctor-patient relationship ${ }^{(31-35)}$.

It should be highlighted that this study has limitations with regard to its internal validity, since a representative 
sample of only one clinic was analyzed ${ }^{(36)}$. As for limitations at the external level, foreign variables could not be controlled, insofar as the topic approached is influenced by subjective aspects, such as culture, education, feelings, emotions, beliefs and values - which influence intern's point of view. The external validity is also conditioned, because it was not possible to generalize locations or samples beyond

\section{References}

1. Puga TF, Benguigui Y. Ensino de pediatria em escolas de medicina da América Latina. Washington: OPAS; 2003.

2. Feuerwerker LC. Além do discurso de mudança na educação médica: processos e resultados. São Paulo: Hucitec; 2002.

3. Gomes AP, Arcuri MB, Cristel EC, Ribeiro RM, Souza LM, Siqueira-Batista RS. Evaluation in medical education: the role of portfolio in curricula based on active methodologies. Rev Bras Educ Med 2010;34:390-6.

4. Marin MJ, Moreno TB, Moravcik MY, Higa EF, Druzian S, Franscischetti I et al. Student's perception of the reflective portfolio in medical school. Rev Bras Educ Med 2010;34:191-8.

5. Savaris RF. Formative assessment among fourth-year medical students: an experience report. Rev Bras Educ Med 2009;33 (Suppl 1):111-5.

6. Veiga $E Q$, Batista NA. Undergraduate teaching of pediatrics in medical schools of the state of Rio de Janeiro. J Pediatr (Rio J) 2006;82:115-20.

7. Silva RF, Sá-Chaves I. Reflexive formation: teachers' representations about the use of reflexive portfolio in the forming of medical doctors and nurses. Interface Comunic Saude Educ 2008;12:721-34.

8. Cotta RM, Silva LS, Lopes LL, Gomes KO, Cotta FM, Lugarinho R et al. The construction of collective portfolios in traditional curriculums: an innovative approach in teaching-learning. Cienc Saude Coletiva 2012;17:787-96.

9. Zeferino AM, Domingues RC, Amaral E. Feedback as a teaching/learning strategy in medical education. Rev Bras Educ Med 2007;31:176-9.

10. Silva RF, Francisco MA. Reflective portfolio: a strategy for medical education. Rev Bras Educ Med 2009;33:562-70.

11. Cunha MI. O professor universitário na transição de paradigmas. Araraquara: JM Editores; 1998.

12. Vieira VM. Portfolio: one proposal of evaluation with remaking to learn process. Psicol Esc Educ (Impr) 2002;6:149-53.

13. Campos S, Pessoa VI. Discutindo a formação de professoras e professores com Donald Shön. In: Geraldi CM, Fiorentini D, Pereira EM, editors. Cartografias do trabalho docente: professor(a) - pesquisador(a). Campinas: Mercado de Letras; 1998. p. 183-206.

14. Prearo AY, Rizzato AB, Martins ST. Pediatrics teaching in primary health care between the boundaries of the biomedical model and the perspective of integrality of care: the view of the supervisor doctors. Interface Comunic Saude Educ 2011;15:1039-52.

15. Sperandio AM, Souza TF, Breno E, Mendes LC, Pereira AR, Machado AC et al. The university collaborating in the construction of a health promotion project: report on an experience of a group of medical students at Unicamp, Campinas, SP, Brazil. Rev Bras Educ Med 2006;30:200-8.

16. Minayo MC. O desafio do conhecimento: pesquisa qualitativa em saúde. $9^{\text {th }}$ ed. São Paulo: Hucitec; 2006.

17. Fontanella BJ, Ricas J, Turato ER. Saturation sampling in qualitative health research: theoretical contributions. Cad Saude Publica 2008;24:17-27.

18. Lefèvre F, Lefèvre AM, Teixeira JJ. O discurso do sujeito coletivo. Uma nova abordagem metodológica em pesquisa qualitativa. Caxias do Sul: Educs; 2000. those studied, only allowing the transfer of conclusions to similar realities ${ }^{(37)}$.

Thus, this critical analysis allowed a summary of interns' reflections, suggestions and criticisms, and can serve as a model to mother and child, internship and medical school coordinators for improvement of the professional cycle $\mathrm{e}^{(33-35)}$.
19. Lefèvre F, Lefèvre AM. O sujeito coletivo que fala. Interface Comunic Saude Educ 2006;10:517-24.

20. Schraiber LB. Qualitative research in health studies: methodological reflections on the oral account and narrative technique in study on the medical profession. Rev Saude Publica 1995;29:63-74.

21. Turato ER. Qualitative and quantitative methods in health: definitions, differences and research subjects. Rev Saude Publica 2005;39:507-14.

22. Neves JL. Pesquisa qualitativa: características, usos e possibilidades. Cad Pesq Administracao 1996;1:1-5.

23. Sene TB, Lino ML, Gonsaga RA, Silva EM, Biscegli TS. Patient's autonomy: a situacional analysis of an emergency unit. Rev Bioet (Impr) 2012;20:518-25.

24. Nunes $P$ [homepage on the Internet]. Conceito de organização [cited 2012 Oct 12]. Available from: http://www.notapositiva.com/trab_professores/ textos_apoio/gestao/03conc_organizacao.htm

25. Gonsaga RA. Manual do internato: ciclos profissionalizantes I e II [monografia] Catanduva (SP): FIPE; 2012.

26. World Health Organization [homepage on the Internet]. The optimal duration of exclusive breastfeeding: results of a WHO systematic review [cited 2010 Sep 10]. Available from: http://www.who.int/inf-pr-2001/en/note2001-07.html

27. Huffman SL, Yeager BA, Levine RE, Shelton J, Labbok M. Breastfeeding saves lives: an estimate of the impact of breastfeeding on infant mortality in developing countries. Bethesda: NUTURE/Center to Prevent Childhood Malnutrition; 1991.

28. Silva Júnior JL, Padilha TF, Rezende JE, Rabelo EC, Ferreira AC, Rabahi MF. Effect of seasonality on the occurrence of respiratory symptoms in a Brazilian city with a tropical climate. J Bras Pneumol 2011;37:759-67.

29. Brasil - Ministério da Saúde - DATASUS [homepage on the Internet]. Morbidade hospitalar do SUS por local de internação - SP [cited 2012 Dec 20]. Available from: http://tabnet.datasus.gov.br/cgi/tabcgi.exe?sih/cnv/nisp.def

30. Pontes AL, Rego S, Silva Junior AG. Teaching conceptions and practice in the transformation of medical education. Rev Bras Educ Med 2006;30:66-75.

31. Wuillaume SM. Educação médica em transformação: instrumentos para a construção de novas realidades. Cad Saude Publica 2005;21:1966-7.

32. Aguiar AC, Ribeiro EC. The concept and evaluation of skills and competence in medical education: current expert perspectives. Rev Bras Educ Med 2010;34:371-8.

33. Rego S, Gomes AP, Siqueira-Batista R. Bioethics and humanization across the curriculum in medical education. Rev Bras Educ Med 2008;32:482-91.

34. Ferreira ML. Avaliação no processo ensino-aprendizagem: uma experiência vivenciada. Rev Bras Educ Med 2003;27:12-9.

35. Forte FD, Viera LB, Pessoa TR, Freitas CH, Ferreira ML. The portfolio system and the challenge of carrying more than classroom notes: the view of dentistry professor. Rev Bras Educ Med 2012;36 (Suppl 2):25-32.

36. Almeida LD, Machado MC. Atitude médica e autonomia do doente vulnerável. Rev Bioet (Impr) 2010;18:165-83.

37. Saraiva AM. Treatment suspension and the ethical values in Intensive Care Units: a survey on the Portuguese reality. Rev Bioet (Impr) 2012;20:150-63. 